\title{
EFFECT OF THE MODEL APPLICATION SETTING INTERACTIVE LEARNING COOPERATIVE LEARNING WITH CONCERN INTEREST AND CAPABILITY TO INITIAL STUDENT LEARNING OUTCOMES GRADE X MIA SMA STATE 2 PANGKAJENE
}

\author{
Nurhayani ${ }^{1}$, Amran Hapsan ${ }^{2}$ \\ ${ }^{1}$ Mathematics Education, Makassar State University \\ ${ }^{2}$ STKIP Pembangunan Indonesia Makassar \\ ${ }^{1}$ matematikamagic@gmail.com
}

\begin{abstract}
Abstrak
Penelitian eksperimen ini bertujuan untuk mengetahui pengaruh model pembelajaran interaktif setting kooperatif dalam pembelajaran matematika siswa kelas X MIA SMA Negeri 2 Pangkajene Tahun Ajaran 2016/2017. Unit eksperimen dalam penelitian ini adalah siswa kelas X MIA Thomas Alfa Edison sebagai kelas perlakuan dan kelas X MIA Ki Hajar Dewantara sebagai kelas kontrol. Unit eksperimen diambil secara random sampling 2 kelas dengan jumlah responden kelas perlakuan sebanyak 27 orang siswa dan kelas kontrol sebanyak 28 orang siswa. Pengambilan data dilakukan melalui tes kemampuan awal siswa, tes hasil belajar matematika siswa, kuesioner minat belajar siswa, dan lembar keterlaksanaan model pembelajaran yang digunakan. Data yang diperoleh diolah dengan menggunakan bantuan program pengolahan data statistik SPSS 20.0. Hasil analisis statistik menunjukkan bahwa hasil belajar matematika siswa kelas $\mathrm{X}$ MIA Thomas Alfa Edison SMA Negeri 2 Pangkajene yang diajar dengan menggunakan model pembelajaran interaktif setting kooperatif dikategorikan sedang dengan skor ratarata 80,52 dengan standar deviasi 9,901 dari skor ideal 100. Minat belajar siswa dikategorikan tinggi dengan skor rata-rata sebesar 147,3 dari skor ideal maksimum 200. Sedangkan lembar keterlaksanaan model pembelajaran siswa dikategorikan terlaksana dengan sangat baik dengan skor rata-rata 3,858. Sedangkan hasil analisis statistik menunjukkan bahwa hasil belajar matematika siswa kelas X MIA Ki Hajar Dewantara SMA Negeri 2 Pangkajene yang diajar dengan menggunakan model pembelajaran konvensional dikategorikan sedang dengan skor rata-rata 68,68 dengan standar deviasi 12 dari skor ideal 100. Minat belajar siswa dikategorikan tinggi dengan skor rata-rata sebesar 141,14 dari skor ideal maksimum 200. Sedangkan lembar keterlaksanaan model pembelajaran siswa dikategorikan terlaksana dengan sangat baik dengan skor rata-rata 3,68. Hasil analisis inferensial terhadap skor kemampuan matematika siswa kelas X MIA Thomas Alfa Edison SMA Negeri 2 Pangkajene yang diajar dengan menggunakan model pembelajaran interaktif setting kooperatif menunjukkan bahwa terdapat pengaruh penerapan model pembelajaran interaktif setting kooperatif dengan memperhatikan minat belajar dan kemampuan awal siswa. Hal tersebut dilihat dari Tabel Hasil Analisis Uji Analisis Kovarians. Dari output Tabel Hasil Analisis Uji Analisis Kovarians diperoleh Sig Corrected Model $=0,000$. Nilai p-value lebih kecil dari $\alpha(0,05)$ yang berarti H_0 ditolak atau $\mathrm{H} \_1$ diterima. Dengan kata lain dapat disimpulkan bahwa terdapat pengaruh penerapan model pembelajaran interaktif setting kooperatif dengan memperhatikan minat belajar dan kemampuan awal siswa.
\end{abstract}

Kata Kunci. Model Interaktif, Minat Belajar, Kemampuan Awal, Hasil Belajar 


\begin{abstract}
This experimental study aimed to determine the effect of learning model interactive cooperative settings in mathematics class X SMA Negeri 2 Pangkajene MIA T ear A distance $2016 / 2017$. The experimental unit in this study was MIA class $\mathrm{X}$ Thomas Alfa Edison as the treatment class and MIA Ki Hajar Dewantara class X as the control class. The experimental unit was taken by random sampling 2 classes with the number of respondents in the treatment class as many as students and the control class as many as 28 students .Data collection was carried out through students' initial ability tests, student mathematics learning achievement tests, student interest questionnaires, and the feasibility sheet of the learning model used. The data obtained were processed using the help of SPSS 20.0 statistical data processing program . The results of statistical analysis show that the mathematics learning outcomes of X MIA Thomas Alfa Edison students at SMA Negeri 2 Pangkajene who are taught using the cooperative learning interactive learning model are categorized as moderate with an average score of 80.52 with a standard deviation of 9.901 from an ideal score of 100. Student learning interests categorized high with an average score of 147.3 from the maximum ideal score of 200. While the sheet of implementation of the learning model of students is categorized very well done with an average score of 3.858. While the results of statistical analysis show that the learning outcomes of students of class X MIA Ki Hajar Dewantara of SMA Negeri 2 Pangkajene taught using conventional learning models are categorized as moderate with an average score of 68.68 with a standard deviation of 12 from an ideal score of 100 . Student learning interest is categorized high with an average score of 141.14 from the maximum ideal score of 200. While the sheet of feasibility of the student learning model is categorized to be implemented very well with an average score of 3.68. The results of the inferential analysis of the mathematics ability scores of class X MIA Thomas Alfa Edison Public High School 2 Pangkajene who were taught using the cooperative learning interactive learning model showed that there was an influence on the application of the interactive learning cooperative cooperative model by paying attention to students' learning interests and initial abilities. This can be seen from the Analysis Results Table for Analysis of Covariance Analysis. From the output of the Analysis Result Test Table, the Covariance Analysis was obtained by the Sig Corrected Model . A value of less than (0.05) which means it is rejected or accepted. In other words it can be concluded that there is an influence on the application of interactive learning models in cooperative settings by paying attention to students' learning interests and initial abilities.
\end{abstract}

Keywords . Interactive Model, Interest in Learning, Early Ability, Learning Outcomes

Citation: Nurhayani, Hapsan, A. 2019. Effect of The Model Application Setting Interactive Learning Cooperative Learning with Concern Interest And Capability to Initial Student Learning Outcomes Grade X MIA SMA State 2 Pangkajene. Matematika dan Pembelajaran, 7(2), 1-12. DOI: http://dx.doi.org/10.33477/mp.v6i2

\title{
PRELIMINARY
}

Some of the causes of ineffective learning processes can come from students, teachers and inadequate facilities and infrastructure, low interest and motivation, and low teacher performance. In the teaching and learning process, the most important thing is the way the teacher teaches or conveys lessons that aim to attract students' attention. Less effective and efficient learning models cause unbalanced cognitive, affective and psychomotor abilities, such as monotonous 
learning from time to time, teachers who are authoritarian and less friendly with students so students feel bored and lack interest in learning. To overcome this, the teacher as a teacher and educator must always improve the quality of his professionalism by providing students with learning opportunities by actively involving students in the teaching and learning process.

Active student involvement in teaching and learning activities is expected to arouse the curiosity of students about certain things. With high interest, it is expected that high curiosity will be something in students and is expected to be able to produce optimal learning outcomes. One learning that can be used so that students can construct their own understanding of a concept while actively interacting socially in learning mathematics is interactive learning cooperative settings (PISK). In the PISK model it is expected that students can always update the level of thinking that is incomplete and the teacher is expected to be able to respect students' opinions, can help students solve problems, can guide students to be able to find out for themselves facts, and concepts learned and can prepare students with the environment, which allows students can gain extensive learning experiences so that students dare to ask questions, express opinions, and can receive opinions from friends.

Based on interviews and the results of preliminary observations obtained from educators in schools, the mathematics learning outcomes of SMA Negeri 2 Pangkajene students are still low especially in class X MIA Thomas Alfa Edison and X MIA Ki Hajar Dewantara. Mathematics learning is still experiencing problems so that mathematics learning outcomes are still relatively low, students' ability to solve problems is generally constrained because students only memorize mathematical formulas without understanding the concept of matter, so that when they forget mathematical formulas, they cannot work on problems and assume that mathematics is a lesson difficult, complicated and boring. When the researcher made preliminary observations about the value of the Minimum Mastery Criteria (KKM) that must be fulfilled by students, information was obtained that students must be able to obtain a grade $\geq 75$ determined by the school as a minimum standard of mastery learning at SMA Negeri 2 Pangkajene. The use of the lecture method makes some students bored so that sometimes they are busy with their respective activities such as drawing or 
doing other homework lessons, some feel insecure in working on the problem because learning is dominated by the teacher.

Therefore the need for changes in learning models that can increase student participation. This is the reason for the writer to try to apply the interactive learning model of cooperative settings. In addition to the learning model used by teachers in the classroom, there are also several factors that can influence student learning outcomes, one of which is the initial ability possessed by each student. Because every student has different initial abilities. So it is important for teachers to know the initial abilities of each student who will be taught before the teacher starts the teaching and learning process in the classroom. Research conducted by $\mathrm{p}$ enulis namely on research Quasi-Experiment, entitled "Effect Setting Application of Interactive Learning Model Cooperative Learning by Watching Interests and Abilities Students Against Early Learning Outcomes MIA Class X SMAN 2 Pangkajene".

\section{THEORITICAL REVIEW}

In programmed and controlled learning activities called learning activities or instructional activities, the learning objectives are predetermined by the teacher. Children who succeed in learning are those who achieve learning goals or instructional goals. According to Sudjana (2008: 34), types of effective learning outcomes appear to students in a variety of behaviors such as attention to learning, discipline, motivation to learn, respecting teachers and classmates, study habits, and social relationships. Learning outcomes are also influenced by intelligence and early mastery of children about the material to be learned

The PISK model is the result of a research development carried out by Tanwey Gerson Ratumanan, a PhD student in Mathematics Education at the State University of Surabaya in 2003. This model is a modification of an interactive model. M odel Interactive Learning consists of five phases as appears in the table below.

Table 1 . Syntax of Interactive Learning Models

\begin{tabular}{ll}
\hline \multicolumn{1}{c}{ Phases } & \multicolumn{2}{c}{ Activity } \\
\hline 1. Introduction & a. Organizing students to learn \\
& b. Tell students what they will do; solve \\
& problems, study a topic, do project work, etc. \\
& c. Determine the problem or activity that \\
& students will do.
\end{tabular}




\begin{tabular}{|c|c|}
\hline Phases & Activity \\
\hline $\begin{array}{ll}2 . & \text { Activity } \\
\text { Troubleshooting }\end{array}$ & $\begin{array}{l}\text { a. Students are involved in mathematical } \\
\text { thinking through the activities of manipulation, } \\
\text { investigation, experimentation or solving a } \\
\text { problem. } \\
\text { b. When students work, the teacher goes around } \\
\text { among students. } \\
\text { c. Students can be given open-ended questions } \\
\text { before class discussion. }\end{array}$ \\
\hline $\begin{array}{l}\text { 3. Share and discuss with } \\
\text { each other }\end{array}$ & $\begin{array}{l}\text { a. Students report the results of their activities, } \\
\text { or the results of solving problems or assignments, } \\
\text { or answers from open-ended. } \\
\text { b. The teacher leads a class discussion. The } \\
\text { teacher can ask questions; "What", "why" and } \\
\text { "how" so that students achieve learning goals. }\end{array}$ \\
\hline 4. $\quad$ Sum up & $\begin{array}{l}\text { a. Students recheck what they have done or } \\
\text { learned, } \\
\text { b. Students demonstrate learning (for example, } \\
\text { solving problems raised by teachers, exchanging } \\
\text { ideas, or making written reports about what they } \\
\text { have learned). }\end{array}$ \\
\hline $\begin{array}{l}\text { 5. Assess learning unit } \\
\text { material }\end{array}$ & $\begin{array}{l}\text { a. Assessment is done before, during and after } \\
\text { learning. } \\
\text { b. Emphasis on students' own assessments }\end{array}$ \\
\hline
\end{tabular}

Initial ability is the ability that students have before participating in learning, because this can illustrate the students' initial readiness to follow the teaching and learning process in the classroom. Where every student has different abilities. There are students who have high, medium and low initial abilities. The initial ability of students is one very important factor in influencing student learning outcomes. The initial ability of students is very important known by the teacher before starting the teaching and learning process, because this is one of the teacher's references so that the teacher knows the extent of student knowledge about the material to be taught in the classroom.

The conditions for effective teaching and learning are students' interest and attention in learning. Interest is a relatively permanent trait in a person, this interest has a great influence on learning because with someone's interest will do something that interests him, otherwise without one's interest it is impossible to do something. For example, if a student has an interest in the field of mathematics education, he will try to find out more about mathematics. Students who have no interest or lack of attention to receive lessons, so as much as possible try to arouse them by providing stimuli from 
the outside, and as a result of children who have no interest, it is difficult for him to have knowledge.

\section{RESEARCH METHODS}

This research is a Quasi Experiment study involving two classes and given different treatments. Treatment classes are taught using interactive learning in a cooperative manner and control classes are taught using conventional learning models. This research will be conducted in the new 2016/2017 academic year semester I at SMA Negeri 2 Pangkajene. The population in this study were all students of class $\mathrm{X}$ MIA SMA Negeri 2 Pangkajene. The samples in this study were two class X MIA namely X MIA Thomas Alfa Edison (TAE) as an experimental class and X MIA Ki Hajar Dewantara (KHD) as a control class that was selected using a simple random sampling technique that is from a population done randomly because there is no class grouping (superior classes), so it is assumed that each class has relatively the same (homogeneous) ability. Experimental class X MIA Thomas Alfa Edison's class of 27 students were taught using the cooperative learning interactive learning model. The experimental class X MIA Ki Hajar Dewantara as many as 28 students were taught using conventional learning models .

This study consists of four stages, namely filling out questionnaires/ questionnaires for students' interest in learning, carrying out pre-tests of subject matter before he was taught, conducting experimental treatment giving using interactive learning models cooperative settings in the experimental class and using models conventional learning in the control class), and the final test implementation.

Data collection techniques carried out by: a) student learning outcomes obtained through pre-test before being given treatment and also through post-test after being given treatment , b) questionnaire used to find out how students' interest in learning mathematics learning material before being taught. Analysis of the data used is descriptive statistical analysis used to describe the characteristics of student mathematics learning outcomes. For the purposes of analysis, the mean, median, mode, standard deviation, variance, minimum value and maximum value are used. Inferential statistical analysis is used to test the research hypothesis using the ANAKOVA test. 
Learning outcomes data are categorized quantitatively based on categorization techniques determined by the Ministry of National Education (Purwanto, 2006: 12) as follows:

Table 2 . Criteria for Completeness of Learning Outcomes

\begin{tabular}{cc}
\hline $\begin{array}{c}\text { The value of learning } \\
\text { outcomes }\end{array}$ & Category \\
\hline $90-100$ & Very high \\
\hline $80-89$ & High \\
\hline $65-79$ & Is \\
\hline $55-64$ & Low \\
\hline $0-54$ & Very low \\
\hline
\end{tabular}

Data about students' interest in learning was obtained from a questionnaire/student's interest in learning in mathematics learning based on the average score of filling out the questionnaire/interest in learning.

\section{RESULTS AND DISCUSSION}

Statistical results relating to scores from the results of students' initial math ability tests before being taught using the interactive learning model of cooperative settings in the experimental group are presented in table 3 below.

Table 3 . Student's Initial Ability Score Statistics Before Being Taught by Using the Interactive Learning Model of Cooperative Settings

\begin{tabular}{cc}
\hline Statistics & Statistical Value \\
\hline Sample Size & 27 \\
Ideal Score & 100 \\
Highest Scores & 46 \\
Lowest score & 2 \\
Range of scores & 44 \\
Average & 18.07 \\
Median & 17 \\
Mode & 12 \\
Standard Deviation & 9,064 \\
Variance & 82,148 \\
\hline
\end{tabular}

Based on table 3 above shows that the average value of the results of the initial ability tests of students consisting of 27 students is 18.07 of the ideal score of 100 that might be achieved. The highest value of students' initial mathematical ability before being taught using the interactive learning model cooperative setting is 46 and the lowest value achieved by students is 2 with a range of scores of 44 . 
Statistical results are related to scores from the results of students' initial mathematical abilities before being taught using the conventional learning model in the control group presented in table 4 below.

Table 4. Statistics Scores of Students' Early Mathematical Ability before being Taught by Using Conventional Learning Models

\begin{tabular}{cc}
\hline Statistics & Statistical Value \\
\hline Sample Size & 28 \\
Ideal Score & 100 \\
Highest Scores & 32 \\
Lowest score & 0 \\
Range of scores & 32 \\
Average & 12.21 \\
Median & 10 \\
Mode & 10 \\
Standard Deviation & 8.35 \\
Variance & 69.73 \\
\hline
\end{tabular}

Based on table 4 above shows that the average value of the results of the initial abilities of students consisting of 28 students is 12.21 of the ideal score of 100 that might be achieved. The highest value of students' initial mathematical ability before being taught using conventional learning models is 32 and the lowest value achieved by students is 0 with a range of scores of 32 .

Statistical results related to the scores of students' mathematics learning outcomes after being taught using the cooperative learning interactive learning model in the experimental group, are presented in table 5 below.

Table 5 . Statistics Students' Mathematical Learning Outcomes After Being Taught Using the Interactive Learning Model of Cooperative Settings

\begin{tabular}{cc}
\hline Statistics & Statistical Value \\
\hline Sample Size & 27 \\
Ideal Score & 100 \\
Highest Scores & 100 \\
Lowest score & 63 \\
Range of scores & 37 \\
Average & 80.52 \\
Median & 80 \\
Mode & 81 \\
Standard Deviation & 9,901 \\
Variance & 98,028 \\
\hline
\end{tabular}


Based on the el 5 tab above shows that the average value of mathematics learning outcomes of students consisting of 27 students is 80.52 of the ideal score of 100 that might be achieved. The highest value of student mathematics learning outcomes after being taught using the cooperative learning interactive learning model is 100 and the lowest score is 63 .

Statistical results related to scores of students' mathematics learning outcomes after being taught using conventional learning models in the control group, are presented in table 6 below.

Table 6 . Statistics Score Students' Mathematical Learning Outcomes After Being Taught By Using Conventional Learning Models

\begin{tabular}{cc}
\hline Statistics & Statistical Value \\
\hline Sample Size & 28 \\
Ideal Score & 100 \\
Highest Scores & 86 \\
Lowest score & 30 \\
Range of scores & 56 \\
Average & 68.68 \\
Median & 70.5 \\
Mode & 70 \\
Standard Deviation & 12 \\
Variance & 144,004 \\
\hline
\end{tabular}

Based on table 6 above shows that the average value of mathematics learning outcomes of students consisting of 28 students is 68.68 of the ideal score of 100 that might be achieved. The highest value of student mathematics learning outcomes after being taught using conventional learning models is 86 and the lowest score is 30 .

Statistical results related to the scores from the results of students' interest in learning mathematics before being taught using the cooperative learning interactive learning model in the experimental group are presented in table 7 below.

Table 7 . Questionnaire Score Statistics Interest in Student Learning Mathematics Before being Taught by Using Interactive Learning Models Cooperative Settings

\begin{tabular}{cc}
\hline Statistics & Statistical Value \\
\hline Sample Size & 27 \\
Ideal Score & 200 \\
Highest Scores & 183 \\
Lowest score & 111 \\
Range of scores & 72 \\
Average & 147.3
\end{tabular}




\begin{tabular}{cc}
\hline Statistics & Statistical Value \\
\hline Median & 149 \\
Mode & 149 \\
Standard Deviation & 16,337 \\
Variance & 266909 \\
\hline
\end{tabular}

Based on table 7 above, it shows that the average value of the results of a student interest in learning mathematics questionnaire test consisting of 27 students is 147.3 from an ideal score of 200 that might be achieved. The highest value of the results of student interest in learning mathematics questionnaire before being taught using the cooperative learning interactive learning model is 183 and the lowest value achieved by students is 111 with a range of scores of 72 .

Statistical results related to scores from the results of students' interest in learning mathematics before being taught by using conventional learning models in the control group are presented in table 8 below.

Table 8 . Questionnaire Score Statistics Interest in Student Learning Mathematics Before being Taught by Using Conventional Learning Models

\begin{tabular}{cc}
\hline Statistics & Statistical Value \\
\hline Sample Size & 28 \\
Ideal Score & 200 \\
Highest Scores & 173 \\
Lowest score & 104 \\
Range of scores & 69 \\
Average & 141.14 \\
Median & 145.5 \\
Mode & 116 \\
Standard Deviation & 18,557 \\
Variance & 344,349 \\
\hline
\end{tabular}

Based on table 8 above shows that the average value of the results of a student interest in learning mathematics questionnaire test consisting of 28 students is 141.14 of an ideal score of 200 that might be achieved. The highest value of the results of student interest in learning mathematics questionnaire before being taught using conventional models is 173 and the lowest value achieved by students is 104 with a range of 69 scores.

Hypothesis testing is done by using covariance analysis (ANAKOVA). The ANAKOVA test results are presented in the following table. 
Table 9. Analysis of Analysis of Covariance Test (ANAKOVA)

\begin{tabular}{lccccc}
\hline \multicolumn{1}{c}{ Source } & $\begin{array}{c}\text { Type III Sum } \\
\text { of Squares }\end{array}$ & df & $\begin{array}{c}\text { Mean } \\
\text { Square }\end{array}$ & F & Sig. \\
\hline Corrected Model & 5184,246 & 3 & 1728,082 & 27,719 & .000 \\
Intercept & 2484,372 & 1 & 2484,372 & 39,850 & .000 \\
Model & 519,459 & 1 & 519,459 & 8,332 & .006 \\
Interest & 10777 & 1 & 10777 & .176 & 677 \\
Initial Ability & 2765,794 & 1 & 2765,794 & 44,364 & .000 \\
Error & 3179,499 & 51 & 62,343 & & \\
Total & 313553,000 & 55 & & & \\
Corrected Total & 8363,745 & 54 & & & \\
\hline
\end{tabular}

Based on the table above, information is obtained that the effect of students 'initial abilities, students' interest in learning and learning models on learning outcomes obtained by students can simultaneously be seen from the significance figures in the Corrected Model section. It is seen that the significance level is 0,000. Because of the significance value at the $95 \%$ confidence level it can be concluded that the learning model significantly influences mathematics learning outcomes by controlling the students' initial abilities and learning interests.

Based on these tables it can be concluded that the learning outcomes of students who are taught using interactive learning models in cooperative settings are higher than those taught by using conventional learning modes .

\section{CONCLUSIONS AND RECOMMENDATIONS}

The learning outcomes of students who are taught using interactive learning models in cooperative settings are higher than the results of learning mathematics students who are taught using conventional learning models. If seen from the average learning outcomes of the experimental class and the control class, the experimental class has a higher average learning outcome compared to the control class. This shows that descriptively student mathematics learning outcomes in the experimental class are higher than the control class.

Researchers can provide the following suggestions: 1) to improve student learning outcomes in mathematics, it is recommended to teachers to make a learning innovation or a kind of learning change so that later student learning outcomes are improved. It is suggested to teachers that it is better to use interactive learning models in cooperative settings, 2) as an educator it should also be noted that the initial abilities possessed by 
students play an important role in increasing student learning outcomes, if students' initial abilities are high then predictable student learning outcomes obtained will at least also be increased, 3) for other researchers in the field of mathematics who intend to develop this research in order to try to use other material to find out whether this learning model can apply to all types of material or only applies to certain materials such as the Linear Equation System and the Squares of Two Variables. In addition, other researchers can try to apply the cooperative learning interactive learning model that has been applied in this study and compare it with other learning models. .

\section{References}

Purwanto, M. Ngalim. 2006. Principles and Techniques of Teaching Evaluation. Bandung: PT Remaja Rosdakarya.

Purwantoro. 2013. Evaluation of Learning Outcomes . Yogyakarta: Student Library.

Sudjana, Nana. 2004. Assessment of Teaching and Learning Results . Bandung: Teen Rosdakarya.

Sudjana, Nana . 2008. Assessment of Teaching and Learning Results. Bandung: PT Remaja Rosda works. 